\title{
Anthrax Edema Toxin Inhibits Nox1- Mediated Formation of Reactive Oxygen Species by Colon Epithelial Cells
}

\author{
Jun-Sub Kim Gary M. Bokoch \\ Departments of Immunology and Microbial Science, and Cell Biology, Scripps Research Institute, \\ La Jolla, Calif., USA
}

\section{Key Words}

Anthrax $\cdot$ cAMP-dependent protein kinase $\cdot$ Colon epithelium • Edema toxin - Innate immunity $\cdot \mathrm{NADPH}$ oxidase $\cdot$ Phosphorylation $\cdot$ Protein kinase A $\cdot 14-3-3$ proteins $\cdot$ Reactive oxygen species

\begin{abstract}
One major route of intoxication by Bacillus anthracis (anthrax) spores is via their ingestion and subsequent uptake by the intestinal epithelium. Anthrax edema toxin (ETX) is an adenylate cyclase that causes persistent elevation of CAMP in intoxicated cells. NADPH oxidase enzymes (Nox1-Nox5, Duox 1 and 2) generate reactive oxygen species (ROS) as components of the host innate immune response to bacteria, including Nox1 in gastrointestinal epithelial tissues. We show that ETx effectively inhibits ROS formation by Nox 1 in HT-29 colon epithelial cells. This inhibition requires the PKAmediated phosphorylation of the Nox1-regulatory component, NoxA1, and the subsequent binding of 14-3-3 3 . Inhibition of Nox1-mediated ROS formation in the gut epithelium may be a mechanism used by $B$. anthracis to circumvent the innate immune response.

Copyright $\odot 2008$ S. Karger AG, Basel
\end{abstract}

\section{Introduction}

The gastrointestinal epithelium serves a primary protective role against food irritants and commensal or pathogenic microbes. Disruption of innate immune responses in the gut causes persistent, chronic inflammatory disease. Often, this can result in the development of inflammation-associated gastrointestinal tumors [1]. Both the development of inflammation and tumor formation have been linked to the formation of reactive oxygen species (ROS) in diseased tissues [2]. NADPH oxidases, particularly Nox1, appear to be the most likely sources for the generation of these oxidants.

The recently described NADPH oxidase (Nox) enzyme family, composed of Nox1, Nox2, Nox3, Nox4, Nox5, Duox1, and Duox2, generate ROS as their primary reaction product [2]. Several of these enzymes, including Nox1, localize to epithelial barrier tissues, where they participate in the innate immune response to microbial infection [1-3]. Nox1 is highly expressed in gastric [4] and colon epithelium and in the colon tumor cell lines Caco2, DLD-1, and HT-29 [5-7], as well as to a lesser extent in a variety of other cell types [2]. It has been shown that lipopolysaccharides from pathogenic Helicobacter pylori strains cause enhanced ROS release by guinea pig gastric pit cells [8], while in a human colon cancer line, T-84, re-

\section{KARGER}

Fax +4161306 1234

E-Mail karger@karger.ch

www.karger.com
(C) 2008 S. Karger AG, Basel

Accessible online at: www.karger.com/jin
Dr. Gary M. Bokoch

Departments of Immunology and Cell Biology - IMM14

10550 North Torrey Pines Road, La Jolla, CA 92037 (USA)

Tel. +1 858784 8217, Fax +1 858784 8218, E-Mail bokoch@scripps.edu 
combinant flagellin from Salmonella enteritidis stimulated ROS-dependent release of IL-8 [9]. Szanto et al. [7] detected high Nox1 mRNA levels in interstitial lymphoid cells of the colon, particularly within inflammatory lesions of ulcerative colitis and Crohn's disease patients.

Structurally, Nox1 is most closely related to Nox 2 of phagocytic leukocytes and, as with the phagocyte NADPH oxidase, superoxide generation by Nox1 requires the membrane co-subunit $\mathrm{p} 22^{\text {phox }}[10,11]$. Nox1 activation also depends on interactions with cytosolic regulatory subunits, including NoxO1, which is a homologue of the phagocyte oxidase $\mathrm{p} 47^{\text {phox }}$ adapter protein, and NoxA1, a homologue of the Nox 2 p67phox 'activator protein' $[12,13]$. Finally, as with Nox2, full Nox1 activity is dependent on the Rac1 GTPase [14-16]. We recently demonstrated the inhibition of Nox1 activity in response to elevation of intracellular cAMP and the resulting activation of cAMP-dependent protein kinase [17]. This resulted in the phosphorylation of NoxA1 at Ser172 and Ser461 and induced the binding of $14-3-3 \zeta$ protein. $14-3-3$ proteins form homo- and heterodimers that can interact with a wide variety of cellular proteins through specific phosphoserine/phosphothreonine-binding motifs (RSXpSXP or RXXpSXP) [18-20]. The effects of 14-3-3 proteins on their targets include inducing conformational changes in the target protein, masking specific region(s) on the target, and acting as a scaffold to regulate localization and/or substrate activity [21].

Bacillus anthracis, the causative agent of anthrax, is a Gram-positive bacterium whose endospores enter the body through skin abrasions, inhalation, or ingestion [22]. Once the host is infected, the B. anthracis spores germinate into vegetative bacilli and secrete multiple virulence factors, including a toxin and an anti-phagocytic poly-D-glutamic acid capsule. The action of the toxin is thought to play a critical role in the pathogenesis of anthrax. Anthrax toxin is a classic 'AB' toxin, composed of three polypeptides. The $\mathrm{B}$ component, protective antigen (PA), binds to two alternative A components, lethal factor (LF) and edema factor (EF), to produce lethal toxin (LTx) and edema toxin (ETx), respectively [reviewed in ref. 22, 23]. For these toxins to gain entry into cells, PA binds to the cell surface receptor tumor endothelial marker-8 (ATR/TEM8) [24] and capillary morphogenesis protein 2 (CMG2) [25]. While CMG2 is widely expressed at low levels [26], ATR/TEM8 is highly expressed in the vasculature of tumors, as well as on epithelial cells in the gastrointestinal tract [27]. Receptor-bound PA is then cleaved by cell surface proteases, leaving a $63-\mathrm{kDa}$ fragment which assembles into a heptameric prepore complex. Up to three molecules of LF and/or EF bind to the prepore complex and the entire toxin complex undergoes receptor-mediated endocytosis. As the complex traffics through the endocytic pathway, it is exposed to increasingly acidic $\mathrm{pH}$ which initiates pore formation by the PA heptamer, ultimately enabling EF and LF to translocate into the cytosol.

$\mathrm{LF}$ is a zinc-dependent metalloprotease that cleaves and inactivates six of the seven mitogen-activated protein kinase (MAPK) kinases (MEKs) [23]. These enzymes are direct activators of the MAPK pathways, which include extracellular-regulated kinase (ERK), p38, and c-Jun amino-terminal protein kinase (JNK). In contrast, $\mathrm{EF}$ is a calcium- and calmodulin-dependent adenylyl cyclase that causes persistent increases in intracellular levels of cAMP [28], subsequently causing the activation of cAMPdependent protein kinase, also known as protein kinase A (PKA) [29].

Clinical findings in individuals infected with $B$. anthracis suggest an early inhibition of the innate immune system $[30,31]$. While considerable research has centered on the effects of anthrax toxin on macrophages, which are clearly critical in the etiology of anthrax, there is little information on the effects of the B. anthracis toxins on other components of the innate immune system, particularly in humans. The formation of ROS by phagocytic leukocytes is important in human host resistance and bacterial killing [32], and both LTx and ETx have been shown to inhibit chemoattractant-induced superoxide production in human neutrophils $[33,34]$. Whether $B$. anthracis is able to antagonize the action of other, nonphagocytic Nox enzymes at sites of intoxication has not been investigated.

In the present study, we show that $B$. anthracis ETx induces the down-regulation of ROS production by Nox1 activity in intestinal epithelial cells. We establish that the mechanism for this inhibitory effect of ETx is the PKAinduced phosphorylation of the Nox1-regulatory component, NoxA1, and the subsequent induction of 14-3-3 $\zeta$ binding to phosphorylated NoxA1. These findings identify a mechanism by which ingested $B$. anthracis may avoid the Nox1-mediated component of the innate immune response of gastrointestinal epithelia.

\section{Materials and Methods}

Cell Culture and Reagents

Human HEK293 cells, human CCD841T colon epithelial cells, and HT-29 colon adenocarcinoma cells were maintained in Dulbecco's modified Eagle's medium (Invitrogen, Carlsbad, Calif., 
USA) containing $10 \%$ heat-inactivated fetal bovine serum (Invitrogen), $1 \mathrm{mM}$ sodium pyruvate, $100 \mu \mathrm{M}$ nonessential amino acids, and antibiotics ( 100 units $/ \mathrm{ml}$ penicillin and $100 \mu \mathrm{g} / \mathrm{ml}$ streptomycin) at $37^{\circ} \mathrm{C}$ in $5 \% \mathrm{CO}_{2}$. The CCD841T cell line was derived from normal human colon epithelia and exhibits a normal epithelial cell (non-transformed) phenotype under the culture conditions utilized (see ATCC catalog). H89, horseradish peroxidase, luminol, and monoclonal anti-Myc antibody were purchased from Sigma. Polyclonal anti-NoxA1 antibody was generated in-house as part of the Centers for Disease Control Program PO1 CI000095. Anti-14-3-3 $\zeta$ antibody was from Santa Cruz Biotechnology (Santa Cruz, Calif., USA), anti-PKA-specific Ser/Thr antibody was from Cell Signaling Technology (Beverly, Mass., USA). ECL reagents were from Pierce, and protein A- or G-Sepharose beads were from Amersham Biosciences (Piscataway, N.J., USA). Anthrax toxins were from Beiresources (Manassas, Va., USA) or were generated in-house.

\section{Plasmids}

pRK5-myc-NoxA1, -NoxA1 mutants (S172A, S461A, or S172/ 461A), pcDNA3.1-HA-PKA-CA, -KD, pcDNA3.1-HA-14-3-3 $\zeta$ or $-14-3-3 \zeta-$ K49E were described previously [17].

\section{Transient Transfections}

HEK293 cells or HT-29 cells were plated at $4 \times 10^{5}$ cells/well in 6-well plates and grown overnight in Dulbecco's modified Eagle's medium with $10 \%$ fetal bovine serum, 100 units $/ \mathrm{ml}$ penicillin, and $100 \mu \mathrm{g} / \mathrm{ml}$ streptomycin to $40-50 \%$ confluence. Cells were transfected with vectors harboring the inserted gene using Lipofectamine 2000, according to the manufacturer's instructions. In all experiments where activity was determined, the expression levels of each transfected protein component were verified to be unaffected under each condition by immunoblot [17].

\section{Measurement of ROS}

ROS were determined using luminol chemiluminescence, as described previously [17]. Cells cultured in six-well plates were harvested by incubation with trypsin/EDTA for $1 \mathrm{~min}$ at $37^{\circ} \mathrm{C}$. After being washed with phosphate-buffered saline (without $\mathrm{MgCl}_{2}$ and $\mathrm{CaCl}_{2}$ ), the cells were removed from the well, washed twice with cold Hanks' balanced salt solution containing calcium and magnesium, then pelleted at $1,000 \mathrm{~g}$ for $5 \mathrm{~min}$ and resuspended in Hanks' balanced salt solution. Chemiluminescence was measured for $30 \mathrm{~min}$ at $37^{\circ} \mathrm{C}$.

\section{Membrane and Cytosol Fractionation}

Cells grown in $10-\mathrm{cm}$ dishes were washed with cold $1 \times$ phosphate-buffered saline, and extracted in ice-cold lysis buffer (100 mM Pipes, pH 7.3, $100 \mathrm{mM} \mathrm{KCl,} 3.5 \mathrm{mM} \mathrm{MgCl}_{2}, 3 \mathrm{~mm} \mathrm{NaCl}, 1 \mathrm{~mm}$ ATP supplemented with $1 \mathrm{mM}$ phenylmethylsulfonyl fluoride, $1 \mu \mathrm{g} / \mathrm{ml}$ aprotinin, $1 \mu \mathrm{g} / \mathrm{ml}$ leupeptin, $1 \mu \mathrm{g} / \mathrm{ml}$ pepstatin, and $1 \mathrm{mM}$ vanadate) for $5 \mathrm{~min}$. Cells were collected by scraping, and cell lysates prepared by sonication four times for $30 \mathrm{~s}$. The resulting homogenates were centrifuged at 3,000 rpm for $10 \mathrm{~min}$ to pellet nuclei and intact cells, and supernatants were then centrifuged at $45,000 \mathrm{rpm}$ at $4^{\circ} \mathrm{C}$ for $60 \mathrm{~min}$ in a refrigerated ultracentrifuge (TL100, Beckman) to sediment plasma membranes. The cytosolcontaining supernatant was removed, and the crude membrane pellet was gently washed with lysis buffer. Membrane fractions were resuspended in lysis buffer, sonicated three times for $30 \mathrm{~s}$, then centrifuged at $45,000 \mathrm{rpm}$ at $4^{\circ} \mathrm{C}$ for $60 \mathrm{~min}$. Membrane and cytosol fractions were then assayed for total protein, and equal amounts $(30 \mu \mathrm{g})$ analyzed by Western blotting. For protein immunoprecipitation experiments, cells were solubilized with sonication in standard radioimmune precipitation assay buffer with $1 \%$ Nonidet P-40 and $0.1 \%$ SDS containing a protease inhibitor mixture for $1 \mathrm{~h}$ at $4^{\circ} \mathrm{C}$, and then centrifuged at $45,000 \mathrm{rpm}$ at $4^{\circ} \mathrm{C}$ for $45 \mathrm{~min}$. Individual proteins were immunoprecipitated using appropriate antibodies and analyzed by Western blotting, as indicated in the figure legends.

\section{Results}

\section{Anthrax ETx Inhibits Nox1 Activity}

ETx was reported to inhibit ROS formation by neutrophils, and these studies implicated the action of cAMPinduced PKA activation in the inhibitory mechanism [29, $33,34]$. Recently, we reported that Noxl activity, which is abundant in colon epithelium, can also be regulated by the action of PKA and 14-3-3 proteins [17]. As the gastrointestinal tract is a major mode of entry of $B$. anthracis endospores, we hypothesized that ETx might inhibit ROS formation in colon epithelial cells as a means to escape host innate immunity. To determine whether ETx influences Nox1 activity, we measured Nox1-dependent ROS production in the HT-29 colon carcinoma cell line, which expresses endogenous Nox1 and Nox1-regulatory components (NoxA1 and NoxO1) $[12,13,35,36]$. In HT-29 cells, the addition of PA or EF alone had no significant effect on Nox1 activity. In contrast, ETx significantly inhibited Nox1 activity (fig. 1a) in a time- (fig. 1b) or concentration-dependent manner (fig. 1c). Both the timing of ETx action and the concentration-response relationship observed are consistent with the results obtained previously for inhibition of the neutrophil Nox2 system [34]. The lack of effect of either PA or EF alone indicates that the action of ETx to inhibit Nox1 activity requires intracellular activity of EF as an adenylate cyclase.

\section{PKA Activity Is Required for Inhibition of NoxI}

by ETx

Since activation of the cAMP/PKA pathway is a wellestablished component of ETx-mediated cellular responses, we sought to determine whether PKA activity was necessary for inhibition of Noxl activity by ETx. In the presence of the PKA inhibitor H89, the effect of ETx to inhibit HT-29 cell Nox1 activity was attenuated (fig. 2a). Similarly, overexpression of a catalytically inactive PKA catalytic subunit (PKA-KD) decreased the action of ETx, while an active PKA catalytic subunit (PKA-CA) inhib- 

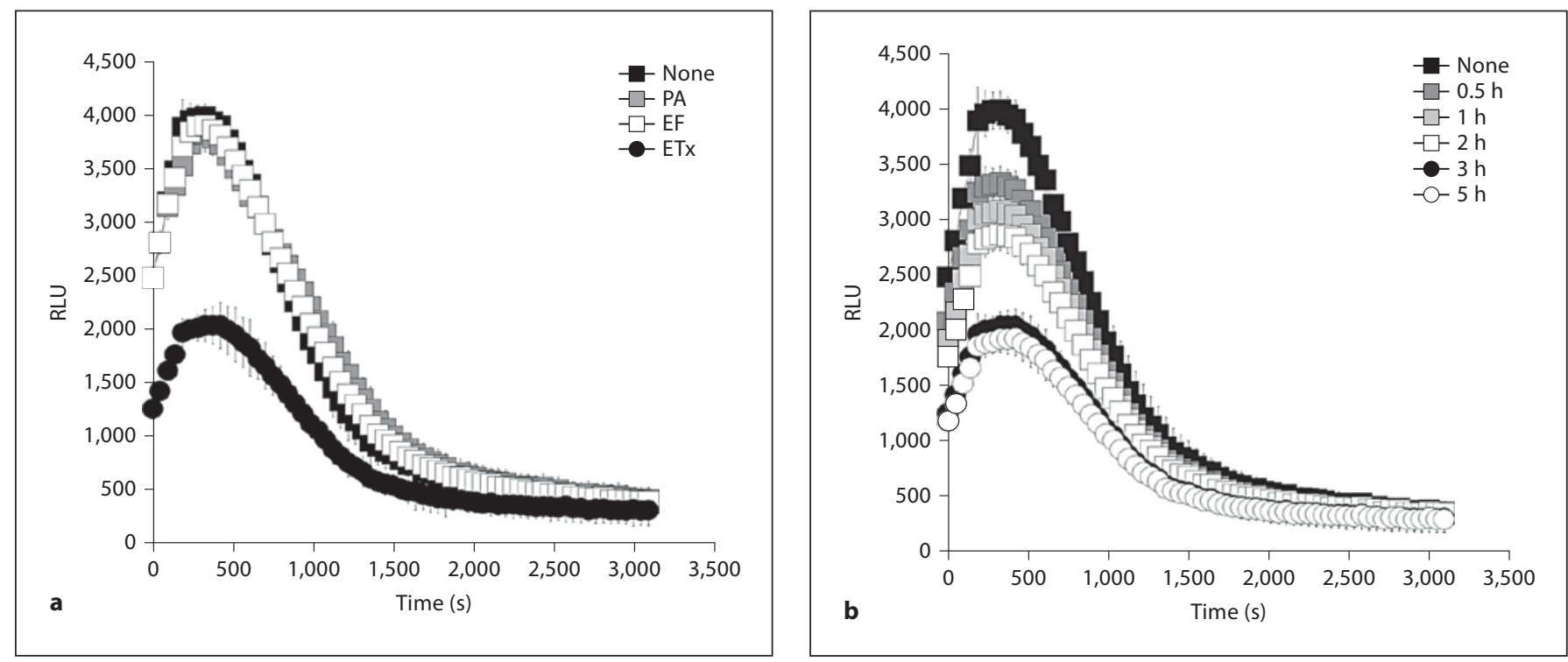

Fig. 1. Anthrax ETx inhibits Nox1 activity in HT-29 cells. a HT-29 cells were treated with or without $1 \mu \mathrm{g} / \mathrm{ml} \mathrm{PA}, 0.5 \mu \mathrm{g} / \mathrm{ml} \mathrm{EF}$, or ETx $(1 \mu \mathrm{g} / \mathrm{ml}$ PA plus $0.5 \mu \mathrm{g} / \mathrm{ml} \mathrm{EF})$ for $3 \mathrm{~h}$. b Cells were exposed to ETx $(1 \mu \mathrm{g} / \mathrm{ml}$ PA plus $0.5 \mu \mathrm{g} / \mathrm{ml} \mathrm{EF})$ for the indicated time periods. c Cells were treated with various doses of ETx $(1 \mu \mathrm{g} / \mathrm{ml}$ PA plus indicated concentration of EF) for $3 \mathrm{~h}$. Nox 1 activity was then determined by chemiluminescence assay. Representative experiments from three separate experiments are shown. RLU = Relative light units.

ited Nox1 activity in a synergistic fashion with ETx (fig. 2b). These results establish that Nox1 activity is negatively regulated by ETx, most likely through its ability to induce PKA activation.

\section{ETx Regulates NoxA1 Localization}

Several prior studies have established that the plasma membrane localization of NoxA1 is critical for Nox 1 activity, and that membrane localization of NoxA1 is dependent on NoxO1 and/or active Rac1 GTPase [14-16]. We recently showed that the membrane localization of NoxA1 was disrupted by PKA activation [17]. Therefore,

we examined whether ETx regulates the subcellular localization of NoxA1 through a similar mechanism. Under the basal condition or upon H89 treatment, endogenous NoxA1 was found to be localized in the HT-29 membrane fraction. In contrast, treatment of the cells with ETx increased the appearance of NoxA1 protein in the cytosolic fraction, and this effect of ETx was reduced in the presence of $\mathrm{H} 89$ (fig. 2c).

\section{ETx Mediates Phosphorylation of NoxA1 via PKA}

Our previous results showed that the relocalization of NoxA1 induced by PKA resulted from the phosphoryla- 

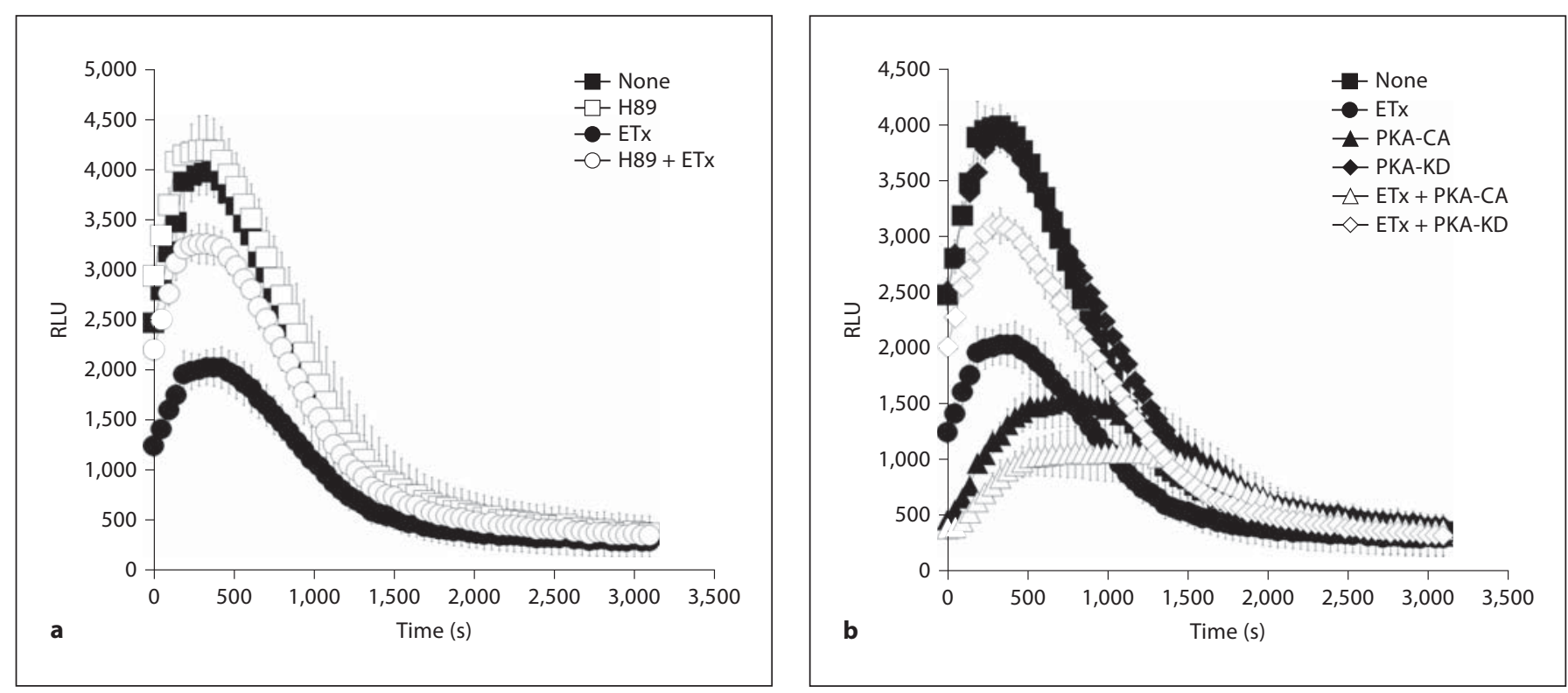

Fig. 2. Inhibition of Nox 1 activity by ETx is mediated via the activation of PKA. a HT-29 cells were pretreated with or without $0.1 \mu \mathrm{M}$ H89 for $30 \mathrm{~min}$ before treatment with ETx (1 $\mu \mathrm{g} / \mathrm{ml} \mathrm{PA}$ plus $0.5 \mu \mathrm{g} / \mathrm{ml} \mathrm{EF}$ ) for $3 \mathrm{~h}$, and then Noxl activity was determined. b pcDNA3-HA-PKA-CA or -PKA-KD were transiently transfected into HT-29 cells for $48 \mathrm{~h}$, and then the cells were treated with or without ETx $(1 \mu \mathrm{g} / \mathrm{ml} \mathrm{PA}$ plus $0.5 \mu \mathrm{g} / \mathrm{ml} \mathrm{EF})$ for $3 \mathrm{~h}$ before Nox 1 activity was measured. $\mathrm{c}$ The cytosol and membrane protein levels of endogenous NoxA1 were examined after treatment with ETx (a) by cell fractionation and immunoblot analysis. Representative experiments from three separate experiments are shown. RLU = Relative light units.

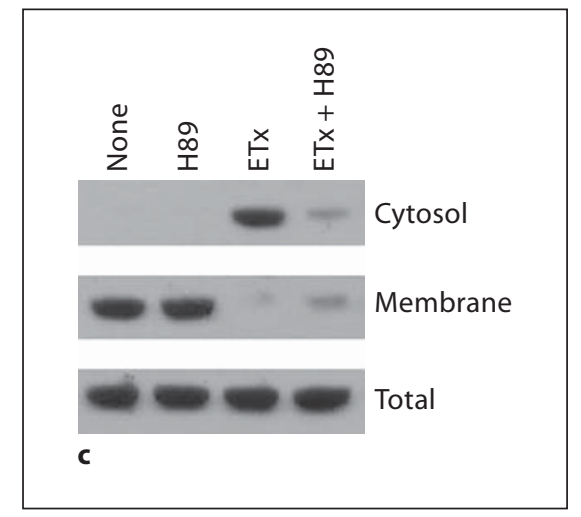

tion of NoxA1 at two specific sites, Ser172 and Ser461 [17]. We therefore examined whether ETx induced the phosphorylation of NoxA1 at these same positions. HEK293 cells were transiently transfected with NoxA1 wild type for $16 \mathrm{~h}$, and treated with or without PA, EF, or ETx. NoxA1 protein was immunoprecipitated, and its phosphorylation state determined by immunoblotting with an anti-phosphoSer/Thr PKA-specific antibody. Phosphorylation of NoxA1 was substantially increased by ETx compared with controls or cells treated with $\mathrm{PA}$ or EF alone (fig. 3a). We next confirmed the ETx-induced phosphorylation sites of NoxA1 and the PKA dependency of NoxA1 phosphorylation. HEK293 cells were transiently transfected with NoxA1 wild type or its phosphorylation site mutants for $16 \mathrm{~h}$, and treated with or without ETx in the presence or absence of the PKA inhibitor H89. As expected, ETx phosphorylation of NoxA1 was lost when both Ser172 and Ser461 were mutated to Ala (fig. 3b). NoxA1 phosphorylation was also inhibited by H89 treatment, in both the wild-type protein and the individual phosphorylation site mutants (fig. 3b). These results indicate that ETx induces the phosphorylation of NoxA1 in a PKA-dependent manner at Ser172 and Ser461.

\section{ETx Induced Phosphorylation of NoxA1 Recruits 14-3-3 $\zeta$ for Inhibition}

We had previously observed that the phosphorylation of NoxA 1 by PKA at Ser172 and Ser461 led to the binding of 14-3-3 proteins with NoxA1, resulting in inhibition of NoxA1 membrane translocation and overall Nox1 activity [17]. Similarly, we were able to observe the interaction of NoxA1 and 14-3-3 $\zeta$ with endogenous phosphorylated NoxA1 in HT-29 cells treated with ETx (fig. 4a). While the presence of $\mathrm{H} 89$ did not affect basal 14-3-3 $\zeta$ binding 
Fig. 3. ETx phosphorylates NoxA1 at Ser172 and Ser461. HEK293 cells were transiently transfected with pRK5-mycNoxA1 for $16 \mathrm{~h}$ before treatment with or without $1 \mu \mathrm{g} / \mathrm{ml} \mathrm{PA}, 0.5 \mu \mathrm{g} / \mathrm{ml} \mathrm{EF}$, or ETx $(1 \mu \mathrm{g} / \mathrm{ml}$ PA plus $0.5 \mu \mathrm{g} / \mathrm{ml} \mathrm{EF})$ for $3 \mathrm{~h}(\mathrm{a})$, or transiently transfected with myc-NoxA1-WT, -NoxA1(S172A), -NoxA1(S461A), or -NoxA1(S172/461A) for $16 \mathrm{~h}$, then preincubated with or without $0.1 \mu \mathrm{M}$ H89 for $30 \mathrm{~min}$ before treatment with ETx $(1 \mu \mathrm{g} / \mathrm{ml}$ PA plus $0.5 \mu \mathrm{g} / \mathrm{ml} \mathrm{EF})$ for $3 \mathrm{~h}$ (b). Immunoprecipitation was carried out using antibody directed against Myc (NoxA1 epitope), and the presence of the phosphorylated NoxAl and total immunoprecipitated NoxA1 was detected using anti-phospho-PKA-specific Ser/Thr (S/T) antibody and anti-Myc antibody, respectively. Representative experiments of two separate experiments are shown.
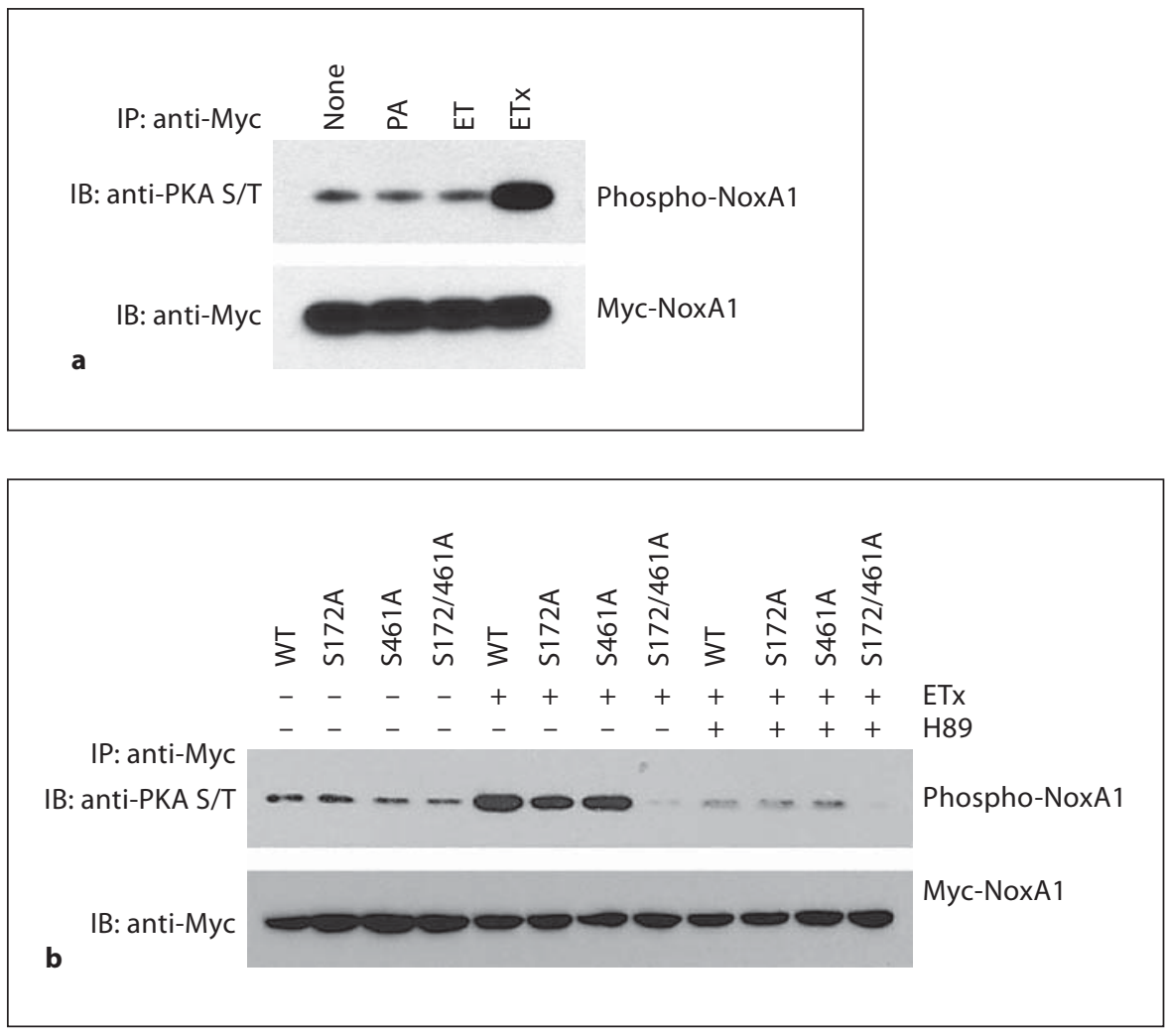

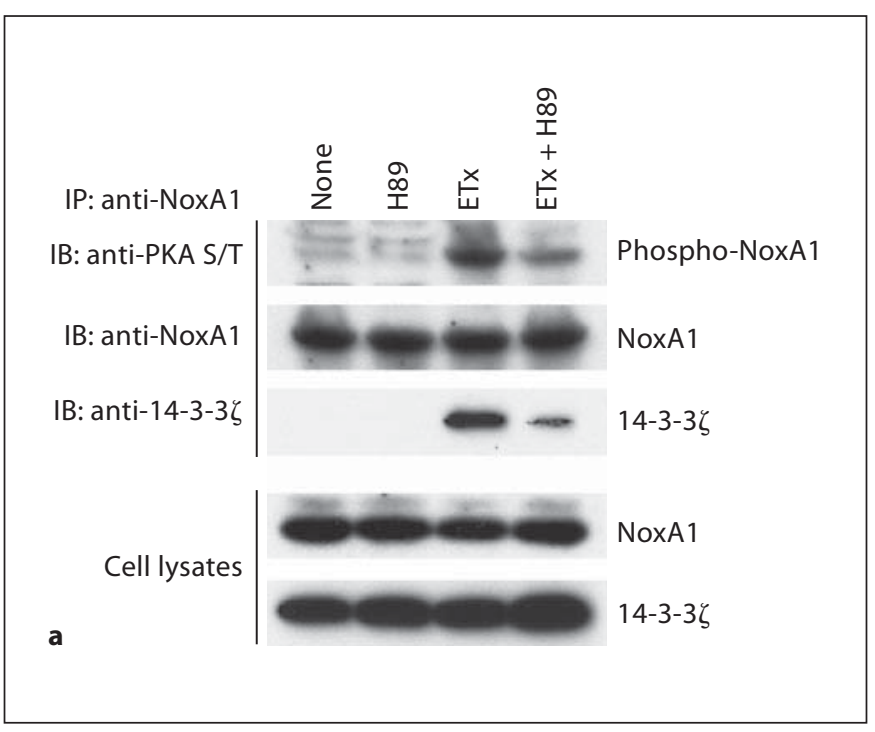

Fig. 4. ETx inhibits Noxl activity by the PKA-mediated recruit-

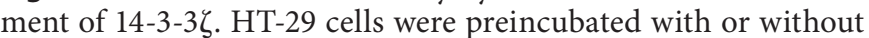
$0.1 \mu \mathrm{M} \mathrm{H} 89$ for $30 \mathrm{~min}$ before treatment with ETx $(1 \mu \mathrm{g} / \mathrm{ml} \mathrm{PA}$ plus $0.5 \mu \mathrm{g} / \mathrm{ml} \mathrm{EF}$ ) for $3 \mathrm{~h}$. Cell lysates were immunoprecipitated with anti-NoxA1 antibody, and phosphorylated NoxA1 and bound 14-3-3 $\zeta$ were detected using anti-phospho-PKA-specific

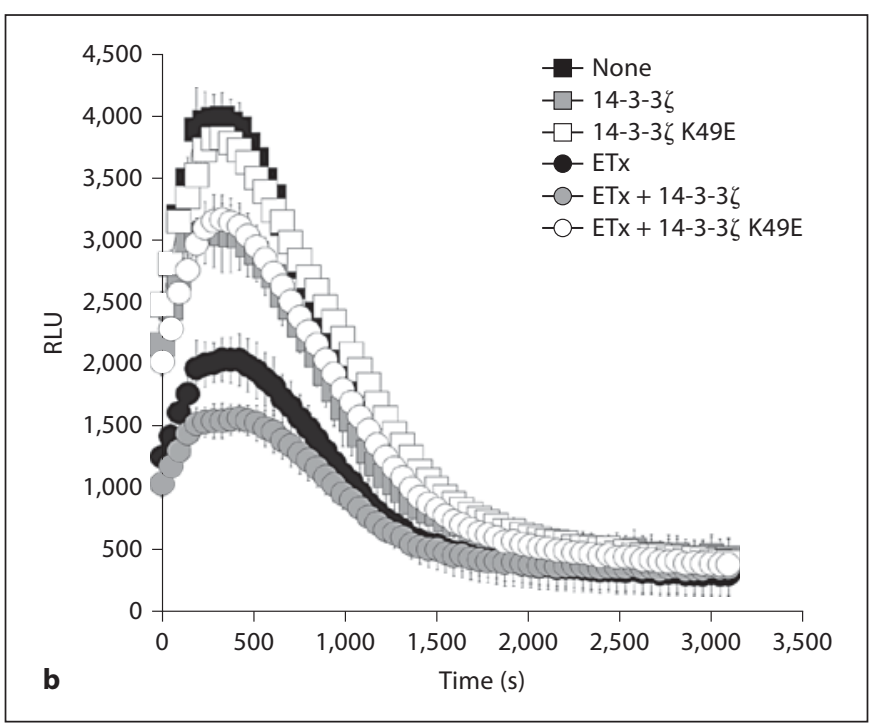

Ser/Thr (S/T) antibody and anti-14-3-3ל antibody, respectively (a). b HT-29 cells were transiently transfected with or without 14-

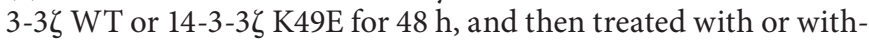
out ETx $(1 \mu \mathrm{g} / \mathrm{ml}$ PA plus $0.5 \mu \mathrm{g} / \mathrm{ml} \mathrm{EF})$ for $3 \mathrm{~h}$ before determining Nox1 activity. Representative experiments from two or three separate experiments are shown. RLU = Relative light units. 
to NoxA1, H89 treatment substantially reduced ETx-induced 14-3-3 $\zeta$ binding to NoxA1, concomitant with inhibition of NoxA1 phosphorylation (fig. 4a). Consistent with these findings, ETx more effectively inhibited Nox1 activity when co-expressed with wild-type 14-3-3 $\zeta$ than in the basal condition (fig. $4 \mathrm{~b}$ ). In contrast, overexpression of $14-3-3 \zeta-\mathrm{K} 49 \mathrm{E}$, a mutant that no longer binds to phosphorylated substrates, dramatically reduced the inhibitory effects of ETx (fig. 4b), suggesting that PKA and 14-3-3 proteins were utilized for inhibition of Nox1 activity by ETx.

\section{Discussion}

Despite the advances in understanding the structure and mode of action of anthrax LTx and ETx in recent years, the intracellular mechanisms modulated by these toxins to regulate innate immune responses have not been fully determined. ETx has been shown to be a highly active $\mathrm{Ca}^{2+}$-calmodulin-regulated adenylate cyclase [28]. The levels of ETx-induced increases in cAMP differ between cell types, but may reach $500-1,000$-fold values, representing conversion of $20-50 \%$ of the cellular ATP stores $[28,29,37]$. The contribution of EF to systemic anthrax is debated, as isogenic EF knockout $B$. anthracis strains are attenuated only 10 -fold in the mouse model for systemic anthrax [38]. The major function of ETx appears to be the suppression of the host innate immune response, thus contributing to the establishment of the infection. Increases in cAMP concentration have many effects on cellular metabolism, most of which are thought to be mediated through PKA. ETx blocks priming of PMNs by muramyl dipeptide or lipopolysaccharide, decreasing the release of superoxide anion caused by subsequent stimulation with chemotactic peptide [33]. We previously showed that ETx inhibited the chemoattractantstimulated formation of ROS by the human neutrophil
Nox2 system through the action of PKA [34]. Therefore, ETx has the potential to disrupt the phagocytic antibacterial responses at several key levels.

There is increasing evidence that Noxl activity and its formation of ROS contributes to the innate immune response to bacterial infection in the gastrointestinal tract [1]. We have recently identified a mechanism for the inhibitory regulation of stimulated Nox1-dependent ROS formation that is mediated via the cAMP $\rightarrow$ PKA-mediated phosphorylation of the Nox1-regulatory component NoxA1 [17]. We showed that this pathway was activated by toxin produced by Vibrio cholerae, a Gram-negative bacterium known to enter the host through the gut epithelium. Here we extend this bacterial immune avoidance mechanism to $B$. anthracis. We show now that Nox1 activity is decreased by ETx in HT-29 colon adenocarcinoma cells (fig. 1), and that this effect is dependent on the stimulation of PKA activity by ETx action (fig. 2). Nox1 inhibition requires the phosphorylation of the Nox1-regulatory protein, NoxA1, at the Ser172 and Ser461 sites (fig. 3b), and this induces the tight binding of $14-3-3 \zeta$ to NoxA1 (fig. 4), resulting in its sequestration in the cytosol (fig. 2c), where it is unable to support the activity of the membrane-localized Nox 1 complex. We observed essentially similar results when we examined the effects of ETx on Nox1 function in CCD841 'normal' (non-transformed) colon epithelial cells (data not shown). We conclude that the suppression of ROS formation in the gut epithelium by secreted ETx may be an important mechanism used by $B$. anthracis to avoid this component of innate immune defense during the infectious process.

\section{Acknowledgments}

We acknowledge the technical assistance of Bruce Fowler, and the advice in use of ETx from Dr. Aimee Decathelineau. This work was supported by Centers for Disease Control grant CI000095 and NIH grant HL48008 (to G.M.B.).

\section{References}

1 Rokutan K, Kawahara T, Kuwano Y, Tominaga K, Sekiyama A, Teshima-Kondo S: NADPH oxidases in the gastrointestinal tract: a potential role of Nox1 in innate immune response and carcinogenesis. Antioxid Redox Signal 2006;8:1573-1582.

$\checkmark 2$ Bedard K, Krause KH: The NOX family of ROS-generating NADPH oxidases: physiology and pathophysiology. Physiol Rev 2007; 87:245-313.
Moskwa P, Lorentzen D, Excoffon KJ, Zabner J, McCray PB Jr, Nauseef WM, Dupuy C, Banfi B: A novel host defense system of airways is defective in cystic fibrosis. Am J Respir Crit Care Med 2007;175:174-183.

4 Tominaga K, Kawahara T, Sano T, Toida K, Kuwano Y, Sasaki H, Kawai T, Teshima-Kondo S, Rokutan K: Evidence for cancer-associated expression of NADPH oxidase 1 (Nox1)based oxidase system in the human stomach. Free Radic Biol Med 2007;43:1627-1638.
5 Perner A, Andresen L, Pedersen G, RaskMadsen J: Superoxide production and expression of $\mathrm{NAD}(\mathrm{P}) \mathrm{H}$ oxidases by transformed and primary human colonic epithelial cells. Gut 2003;52:231-236.

-6 Suh YA, Arnold RS, Lassegue B, Shi J, Xu X, Sorescu D, Chung AB, Griendling KK, Lambeth JD: Cell transformation by the superoxide-generating oxidase Mox1. Nature 1999; 401:79-82. 
7 Szanto I, Rubbia-Brandt L, Kiss P, Steger K, Banfi B, Kovari E, Herrmann F, Hadengue A, Krause KH: Expression of NOX1, a superoxide-generating NADPH oxidase, in colon cancer and inflammatory bowel disease. J Pathol 2005;207:164-176.

-8 Kawahara T, Teshima S, Oka A, Sugiyama T, Kishi K, Rokutan K: Type I Helicobacter pylori lipopolysaccharide stimulates Toll-like receptor 4 and activates mitogen oxidase 1 in gastric pit cells. Infect Immun 2001;69: 4382-4389.

-9 Kawahara T, Kuwano Y, Teshima-Kondo S, Takeya R, Sumimoto H, Kishi K, Tsunawaki S, Hirayama T, Rokutan K: Role of nicotinamide adenine dinucleotide phosphate oxidase 1 in oxidative burst response to Toll-like receptor 5 signaling in large intestinal epithelial cells. J Immunol 2004;172:30513058.

10 Ambasta RK, Kumar P, Griendling KK, Schmidt HH, Busse R, Brandes RP: Direct interaction of the novel Nox proteins with p22phox is required for the formation of a functionally active NADPH oxidase. J Biol Chem 2004;279:45935-45941.

- 11 Hanna IR, Hilenski LL, Dikalova A, Taniyama Y, Dikalov S, Lyle A, Quinn MT, Lassegue B, Griendling KK: Functional association of nox1 with p22phox in vascular smooth muscle cells. Free Radic Biol Med 2004;37:1542-1549.

-12 Banfi B, Clark RA, Steger K, Krause KH: Two novel proteins activate superoxide generation by the NADPH oxidase NOX1. J Biol Chem 2003;278:3510-3513.

13 Geiszt M, Lekstrom K, Witta J, Leto TL: Proteins homologous to p47phox and p67phox support superoxide production by $\mathrm{NAD}(\mathrm{P}) \mathrm{H}$ oxidase 1 in colon epithelial cells. J Biol Chem 2003;278:20006-20012.

14 Ueyama T, Geiszt M, Leto TL: Involvement of Racl in activation of multicomponent Nox1- and Nox3-based NADPH oxidases. Mol Cell Biol 2006;26:2160-2174.

-15 Miyano K, Ueno N, Takeya R, Sumimoto H: Direct involvement of the small GTPase Rac in activation of the superoxide-producing NADPH oxidase Nox1. J Biol Chem 2006; 281:21857-21868.

16 Cheng G, Diebold BA, Hughes Y, Lambeth JD: Nox1-dependent reactive oxygen generation is regulated by Racl. J Biol Chem 2006; 281:17718-17726.
Kim JS, Diebold BA, Babior BM, Knaus UG, Bokoch GM: Regulation of Nox1 activity via protein kinase A-mediated phosphorylation of NoxA1 and 14-3-3 binding. J Biol Chem 2007;282:34787-34800.

18 Muslin AJ, Tanner JW, Allen PM, Shaw AS: Interaction of 14-3-3 with signaling proteins is mediated by the recognition of phosphoserine. Cell 1996;84:889-897.

19 Rittinger K, Budman J, Xu J, Volinia S, Cantley LC, Smerdon SJ, Gamblin SJ, Yaffe MB: Structural analysis of 14-3-3 phosphopeptide complexes identifies a dual role for the nuclear export signal of 14-3-3 in ligand binding. Mol Cell 1999;4:153-166.

20 Yaffe MB, Rittinger K, Volinia S, Caron PR, Aitken A, Leffers H, Gamblin SJ, Smerdon SJ, Cantley LC: The structural basis for 14-3-3: phosphopeptide binding specificity. Cell 1997;91:961-971.

21 Bridges D, Moorhead GB: 14-3-3 proteins: a number of functions for a numbered protein. Sci STKE 2005;2005:re10.

22 Collier RJ, Young JA: Anthrax toxin. Annu Rev Cell Dev Biol 2003;19:45-70.

23 Young JA, Collier RJ: Anthrax toxin: receptor binding, internalization, pore formation, and translocation. Annu Rev Biochem 2007; 76:243-265.

24 Bradley KA, Mogridge J, Mourez M, Collier RJ, Young JA: Identification of the cellular receptor for anthrax toxin. Nature 2001;414: 225-229.

25 Scobie HM, Rainey GJ, Bradley KA, Young JA: Human capillary morphogenesis protein 2 functions as an anthrax toxin receptor. Proc Natl Acad Sci USA 2003;100:51705174.

26 Scobie HM, Young JA: Interactions between anthrax toxin receptors and protective antigen. Curr Opin Microbiol 2005;8:106-112.

27 Bonuccelli G, Sotgia F, Frank PG, Williams TM, de Almeida CJ, Tanowitz HB, Scherer PE, Hotchkiss KA, Terman BI, Rollman B, Alileche A, Brojatsch J, Lisanti MP: ATR/ TEM8 is highly expressed in epithelial cells lining Bacillus anthracis' three sites of entry: implications for the pathogenesis of anthrax infection. Am J Physiol Cell Physiol 2005; 288:C1402-C1410.
28 Leppla SH: Anthrax toxin edema factor: a bacterial adenylate cyclase that increases cyclic AMP concentrations of eukaryotic cells. Proc Natl Acad Sci USA 1982;79:3162-3166.

29 O’Brien J, Friedlander A, Dreier T, Ezzell J, Leppla S: Effects of anthrax toxin components on human neutrophils. Infect Immun 1985;47:306-310.

- 30 Guarner J, Jernigan JA, Shieh WJ, Tatti K, Flannagan LM, Stephens DS, Popovic T, Ashford DA, Perkins BA, Zaki SR: Pathology and pathogenesis of bioterrorism-related inhalational anthrax. Am J Pathol 2003;163: 701-709.

- 31 Jernigan JA, Stephens DS, Ashford DA, Omenaca C, Topiel MS, Galbraith M, Tapper M, Fisk TL, Zaki S, Popovic T, Meyer RF, Quinn CP, Harper SA, Fridkin SK, Sejvar JJ, Shepard CW, McConnell M, Guarner J, Shieh WJ, Malecki JM, Gerberding JL, Hughes JM, Perkins BA: Bioterrorism-related inhalational anthrax: the first 10 cases reported in the United States. Emerg Infect Dis 2001;7:933-944.

-32 Bokoch GM: Regulation of innate immunity by Rho GTPases. Trends Cell Biol 2005;15: 163-171.

33 Wright GG, Mandell GL: Anthrax toxin blocks priming of neutrophils by lipopolysaccharide and by muramyl dipeptide. J Exp Med 1986;164:1700-1709.

34 Crawford MA, Aylott CV, Bourdeau RW, Bokoch GM: Bacillus anthracis toxins inhibit human neutrophil NADPH oxidase activity. J Immunol 2006;176:7557-7565.

- 35 Gianni D, Bohl B, Courtneidge SA, Bokoch $\mathrm{G}$ : The involvement of the tyrosine kinase cSrc in the regulation of reactive oxygen species generation mediated by the NADPH oxidase-1. Mol Biol Cell 2008;19:2984-2994.

- 36 Takeya R, Ueno N, Kami K, Taura M, Kohjima M, Izaki T, Nunoi H, Sumimoto $\mathrm{H}$ : Novel human homologues of $\mathrm{p} 47 \mathrm{phox}$ and p67phox participate in activation of superoxide-producing NADPH oxidases. J Biol Chem 2003;278:25234-25246.

- 37 Kumar P, Ahuja N, Bhatnagar R: Anthrax edema toxin requires influx of calcium for inducing cyclic AMP toxicity in target cells. Infect Immun 2002;70:4997-5007.

38 Pezard C, Berche P, Mock M: Contribution of individual toxin components to virulence of Bacillus anthracis. Infect Immun 1991;59: 3472-3477. 